\title{
Influence of In-service Preschool Teachers' Education on their Perceived Competences for Counselling Parents
}

Sanja Skočić Minić ${ }^{* 1}$, Danijela Blanuša Trošelj² and Vesna Katić ${ }^{2}$

$\approx$ With a half-century of tradition, early and preschool education in the Republic of Croatia is a highly organised system in which preschool teachers meet high professional standards. Among their professional requirements, they have been legally bound to counsel parents since 2008 . However, no other documents or papers in Croatia describe or specify what counselling entails.

The present research explored 136 preschool teachers and their self-assessment of competence in counselling parents. The results indicate that: (a) preschool teachers rate themselves moderately competent in counselling parents; (b) joining the in-service training is related to a higher level of their self-assessment in counselling parents. Although it is evident that they had acquired the competence for counselling parents during their personal and professional development, the in-service training plays the key role in providing it.

Keywords: competence, counselling parents, preschool teachers

$1 \quad{ }^{\star}$ Corresponding Author. Faculty of Teacher Education, University of Rijeka, Croatia; sskocicmihic@gmail.com.

2 Faculty of Teacher Education, University of Rijeka, Croatia. 


\section{Vpliv programov izpopolnjevanja za vzgojitelje na njihovo predstavo o kompetencah za svetovanje staršem}

Sanja Skočić Mihić, Danijela Blanuša Trošelj in Vesna Katić

$\propto$ Zgodnje in predšolsko izobraževanje je v Republiki Hrvaški visoko organiziran sistem s polstoletno tradicijo. V njem se vzgojiteljice in vzgojitelji spoprijemajo $\mathrm{z}$ visokimi profesionalnimi standardi. Od leta 2008 so vzgojiteljice in vzgojitelji pravno zavezani, da svetujejo staršem, kar je ena izmed njihovih številnih nalog. Kljub temu na Hrvaškem ne obstajajo izvedbena pravila ali dokumenti, ki bi opisovali ali podrobneje določali sestavine svetovanja. Ta študija je vključila 136 vzgojiteljic/vzgojiteljev in je ocenjevala njihovo predstavo o kompetencah za svetovanje staršem. Rezultati so pokazali, da: a) vzgojitelji sami sebe ocenjujejo kot zmerno kompetentne za svetovanje staršem; b) da je vključevanje v programe izpopolnjevanja povezano $\mathrm{z}$ višjo ravnjo samoocene pri svetovanju staršem. Čeprav je očitno, da so vzgojiteljice pridobile kompetence za svetovanje staršem med osebnim in profesionalnim razvojem, programi izpopolnjevanja kljub temu igrajo ključno vlogo pri zagotavljanju tovrstnih kompetenc.

Ključne besede: kompetence, svetovanje staršem, vzgojitelji 


\section{Introduction}

Croatian Early Childhood Education and Care (ECEC), known as 'preschool education', is governed by the Law of Preschool Education (1997). It is a unique system under the aegis of the Ministry of Science, Education, and Sport and is financed by the local community. Unlike most European countries, e.g. Austria, Belgium, Germany, France, Ireland (Oberhuemer, Schreyer, \& Neuman, 2010), Croatian preschool institutions include children from the age of six months to the start of primary school (average 6.5 years). These institutions are called preschools ${ }^{3}$ and the professionals who work there are called preschool teachers. ${ }^{4}$ They spend 5.5 hours a day working directly in a same-age or mixedage group of children, with a weekly total of 27.5 hours $(68.25 \%)$ of work (The State Pedagogical Standard of Preschool Education, 2008; a29). Other weekly duties in the remaining 12.5 hours (31.25\%) include their preparation for work, cooperation with parents, and in-service training. The qualifications of almost all employed preschool teachers range from college to master's degrees. Their education has a long tradition and has been organised at the university level since 1969/70 (Babić \& Kuzma, 2003). It has gone through numerous transformations of institutions providing programmes, ${ }^{5}$ curriculums, and degree levels. ${ }^{6}$ According to the Bologna process, the current education system in Croatia is 'based on competence and student achievement/learning outcomes' (Curriculum of study programs, 2013; National Curriculum Framework for Primary Education and General and Compulsory Secondary Education, 2011, p. 9). Recently, preschool teachers have been required to improve their competences in cooperation with parents by using counselling skills, since these are recognised as a part of their work. Although their obligation to counsel parents is obvious (The State Pedagogical Standard of Preschool Education, 2008, a.29, p. 2), no document or paper specifically describes what counselling is in the domain of preschools teachers' work.

Counselling, as a broad term, includes a variety of approaches and processes depending on the social context in different communities. Counselling has many definitions and meanings and depends on many different fields of which it is a part, such as psychology, social work, mental health, the private sector, politics, etc. In human service professions, it is closely connected to

3 In Croatian language - 'vrtić'.

4 In Croatian language - 'odgajatelj.

5 (1) Pedagogy Academy, (2) Faculty of Pedagogy, (3) Teacher Education College Rijeka, (4) Faculty of Teacher Education (Vujičić, Čepić, Lazzarich, 2010).

6 (1) 1969/70-2000/2001, 2-year college program; (2) 2001/02-2008/09, 3 years university study;

(3) 2009/10 until the present moment as a 3-year university study; (4) $2010 / 11$ started the Master's level, 2-year graduated program for preschool teachers. 
terms such as guidance and psychotherapy. Guidance and counselling differ more clearly (Idowu, 2004; Ipaye, 1995) than counselling and psychotherapy do (Janković, 1997; Nelson-Jones, 2003; Resman, 2000). 'Both counseling and psychotherapy represent diverse rather than uniform knowledge and activities, and both use the same theoretical model' (Nelson-Jones, 2015, p. 3). Psychotherapy is longer-term and deeper; it is associated with medical settings and deals with mental disorders, 'whereas counseling relates more to activities in non-medical settings' (Nelson-Jones, 2015, p. 4).

A unified definition adopted by the majority of counselling associations in the United States at the ACA Conference in Pittsburgh 2010 sees counselling as a professional relationship that empowers diverse individuals, families, and groups to accomplish mental health, wellness, education, and career goals' (Kaplan, Tarvydas, \& Gladding, 2014, p. 366). According to Nelson-Jones (2003, p. 9), various considerations that define counselling include 'viewing it as a relationship, a repertoire of interventions, a psychological process, and in terms of its goals and clients'. In the theoretical context, there are more than 400 approaches that can be reduced to five dominant fields: psychodynamic, cognitive-behavioural, humanistic, transpersonal, and systemic (Hackney \& Cormier, 2012).

Counselling may be found in different professions, fields, societies, and scopes. Nelson-Jones (2007, p. 4) defines four categories of people who might offer help: '(1) professional counsellors and psychotherapists, (2) counsellors volunteers and helpers, (3) those who use counselling and helping skills as part of their work, and (4) informal helpers'. Counsellor education is a formal discipline with a century of tradition in America (Savickas, 2011). In contrast, there is no counsellor profession in Croatia (National Classification of Occupations, 2010) and counselling is only mentioned in the domain of social workers in the nomenclature of human service professions. In educational settings, counselling is provided by experts such as psychologist and pedagogues in preschools and schools (Resman, 2000). Generally, counselling as a way of seeking quality outcomes in resolving problems is common in Croatian society (Janković, 1997), but there is a resistance to institutional engagement.

Counselling in educational settings can be directed to children and parents (Doikou \& Diamandidou, 2011). This paper is focused on the provision of counselling as a support to parents of preschool children. The social responsibility of early and preschool institutions in providing support to families has been legally acknowledged (The Council of the European Union, 2009, 2011; UN Convention on the Rights of the Child, 2002; The Council of Europe, 2006; The Council of the European Union, 2006). Formally, findings in neuroscience 
on the family and environment influence on child development (Bowman, Donovan, \& Burns, 2000; Rushton \& Larkin, 2001; Shonkoff \& Phillips, 2000) have been increasingly significant. Family support is based on informing and educating parents in an educational institution (The Croatian National Family Policy, 2003) as part of the concept of partnership with parents. Recently, this concept has been a leading topic of education in the European Union. Moreover, in Croatia, regular and ongoing cooperation with parents is considered to be a parameter of quality preschool institutions (National Curriculum Framework for Primary Education and General and Compulsory Secondary Education, 2011).

Collaboration with parents requires high standards from the preschool teachers' profession (Tankersley et al., 2012; Tuna et al., 2011). The society has assumed a part of the responsibility by assigning parents the right to information, counselling, financial and other assistance, and support in caring for children (Pećnik \& Starc, 2010). Counselling is a possible way of parent support in preschools, but just how preschool teachers can provide counselling is vague. It is evident that preschool teachers belong to the third category of counsellors, according to Nelson-Jones (2003), whose primary focus in work is teaching and the use of counselling skills is limited in terms of time if they are to provide maximum efficiency.

It should be taken into consideration that training/university programmes for preschool teachers are focused mainly on their preparation for educational work with children and less with parents. Teacher faculties in Croatia include one mandatory course on collaboration with parents and no mandatory/elective courses for counselling parents at the undergraduate level. The graduate part-time master's programme at the Faculty of Teacher Education in Rijeka only offers one elective counselling course in the first semester for which students gain five credit points for specific competences, such as (1) explaining the basic theoretical framework of counselling: its process, phases, and framework of a non-directive approach, (2) implementing counselling skills in specific preschool situations, and (3) demonstrating communication skills in counselling parents. Teachers are expected to competently conduct high-quality counselling of parents over the entire spectrum of general and specific competences (Osgood, 2010; Zambo, 2008). New trends in the professional development of teachers are moving towards the gradual shift away from the traditional notions of knowledge as being a linear and simple transfer process, and toward the development of research and reflective skills, which lead to the awareness and additional work in developing the qualities of personal and professional activity (Slunjski, 2008). Self-reflection is the major topic in 
the professional development of preschool teachers, and it is the key feature in responding to the new paradigm of childhood.

Obviously, without pre-service training preschool teachers gain counselling skills predominantly through in-service training. Foreign-language sources of counselling are abundant (Agbaje \& Eyo, 2011), but when it comes to Croatia, there is a lack of sources (Janković, 1997; Resman, 2000), especially in the context of preschool education, in which there is neither research nor theoretical analyses. Therefore, the aim of this research is focused on the preschool teacher's self-assessed ability to counsel parents and on the effects of their age, the experience of teaching, the degree of qualification, and pre/in-service training in counselling on the level of self-assessed ability.

\section{Method}

\section{Participants}

A sample of 136 preschool teachers was selected in accordance with the cluster sampling system. The first cluster included preschool teachers who attended a part-time university graduate study of Early and Preschool Education at the Faculty of Teacher Education, the University of Rijeka in Croatia. Research with the graduate students was conducted on two occasions: the first in December, in the 2010/2011 academic year, and the second in 2011/2012. Due to the small number of participants in the study belonging to the preschool teacher category, who enrolled in the graduate level in the first $(\mathrm{N}=46)$ and the second $(\mathrm{N}=26)$ generations, the sample was expanded. The sample of preschool teachers in the second cluster was extended to preschool teachers who were willing to participate, but they were not students on the graduate study level.

The questionnaires were distributed among the students on two occasions at the beginning of the study programme in the first week of lectures. Other preschool teachers filled out the questionnaires in preschools at which they were employed in January 2012. They were informed that they were free to refrain from completing the questionnaires.

All preschool teachers were female, of average age 35 (range: 22-60) and with 12 years of experience in teaching (range: $0-40$ ). One-half of the preschool teachers had received a two-year college initial education and the other half a three-year education. Teachers were asked if they had any pre/in-service training for counselling parents. The resulting data are presented in Table 1. 
Preschool Teacher Demographics

\begin{tabular}{llccc}
\hline & & Frequency & Percentage & Total \\
\hline \multirow{2}{*}{ Degree of qualification } & 2 years & 67 & 49.3 & 131 \\
& 3 years & 64 & 47.1 & \\
\hline \multirow{2}{*}{ Pre-service training for counselling parents } & No & 105 & 77.8 & 135 \\
& Yes & 30 & 22.1 & \\
\hline \multirow{2}{*}{ In-service training for counselling parents } & No & 97 & 71.3 & 132 \\
& Yes & 35 & 25.7 & \\
\hline
\end{tabular}

\section{Measures}

A questionnaire was developed with the aim of testing whether preschool teachers recognise the concept of counselling parents in their work. Due to the lack of study in this field and its vague concept, the scale of preschool teachers' ability to counsel parents was constructed only with its fundamental dimension: preschool teachers' knowledge, education, experience, and feeling of competence for counselling parents. Self-perceived competence for counselling parents on these four items was measured with a Likert-type scale where 1 is no, 2 is very little, 3 is moderate, 4 is a lot, and 5 is entirely competent. One factor was obtained with high reliability (Cronbach's Alpha =.90) (Skočić Mihić, Blanuša Trošelj, \& Katić, 2015). Furthermore, the preschool teachers' demographic data, such as age, teaching experience, level of degree, and pre- and in-service education about counselling were explored.

\section{Data analysis}

The statistical analyses incorporated a variety of techniques for exploring research questions. Descriptive statistics are presented in the form of frequencies, means, and standard deviation to describe the teachers' perceived competence for counselling parents. Regression analysis was used to predict to what extent the preschool teachers' demographic aspects affect their level of perceived competence for counselling parents. Data were analysed using SPSS for Windows. 


\section{Results}

Teachers were asked to estimate the importance of counselling parents in preschool teachers' work and their motivation for it. The results indicated that they see counselling parents as a significant aspect of their professional work $(\mathrm{M}=4.61, \mathrm{SD}=.53)$ and that they are largely motivated to counsel parents $(\mathrm{M}=4.29, \mathrm{SD}=.76)$. There is a significant correlation between the teachers' opinion about the importance of counselling parents in preschool teachers' work and the motivation to counsel parents $(\mathrm{r}=.23 ; \mathrm{p}<.01)$. Those teachers who are more convinced that counselling parents is an essential part of their job are highly motivated to implement it.

Preschool teachers $(\mathrm{N}=136)$ perceived themselves to be moderately capable of counselling parents in terms of their feeling of competence $(\mathrm{M}=3.00$; $\mathrm{SD}=.87)$, knowledge $(\mathrm{M}=2.87 ; \mathrm{SD}=.81)$, experience $(\mathrm{M}=2.86 ; \mathrm{SD}=.95)$, and training $(\mathrm{M}=2.38 ; \mathrm{SD}=1.04)$. They assessed themselves as moderately capable of counselling parents according to the arithmetic mean $2.78(\mathrm{SD}=.81)$. The responses were factor-analysed, and the obtained factor is called Factor of selfperceived competence for counselling parents (Skočić Mihić et al., 2015).

We did not find a correlation between the teachers' perceived competence for counselling parents and their opinion of the importance of counselling in their professional work and motivation for its implementation $(r=.058$; $\mathrm{p}>.05$, and $\mathrm{r}=.108 ; \mathrm{p}>.05)$.

Hierarchical regression was used to predict the preschool teachers' level of self-assessed competence for counselling parents.

Table 2

Results of Multiple Regression Analysis in Predicting Teachers' Perceived Competence for Counselling Parents

\begin{tabular}{lcccccc}
\hline \multirow{2}{*}{ Variable } & \multicolumn{3}{c}{ Model 1 } & \multicolumn{3}{c}{ Model 2 } \\
\cline { 2 - 7 } & B & SE B & $\beta$ & B & SE B & $\beta$ \\
\hline Age & -.019 & .018 & -.226 & & & \\
Experience teaching & .049 & .017 & $.627^{* *}$ & & & \\
Degree of qualification & -.300 & .117 & $-.206^{*}$ & & & \\
\hline Age & & & -.004 & .468 & -.049 \\
Experience teaching & & & .027 & .016 & .351 \\
Degree of qualification & & & -.181 & .015 & -.124 \\
Pre-service training & & & .241 & .106 & .122 \\
In-service training & & & .73 & .135 & $.423^{* * *}$ \\
\hline $\mathrm{R}^{2}$ & & & & .438 & \\
\hline $\mathrm{F}$ for $\mathrm{R}^{2}$ & & & & & & \\
\hline
\end{tabular}

Note. ${ }^{*} p<.05 ;{ }^{* *} p<.01 ;{ }^{* * *} p<.00$ 
In the first step, teaching experience and the level of degree yield a significant relationship $\left(\mathrm{R}=.523, \mathrm{R}^{2}=.278, \mathrm{p}<.00\right)$ and explain $16 \%$ of the total variance. Pre- and in-service education for counselling parents $(1=$ had education), entered in the second step, predicted a statistically significant $(\mathrm{R}=.662$, $\mathrm{R}^{2}=.278, \mathrm{p}<.00$ ) level of preschool teachers' competence to counsel parents, over and above the variance explained in the first step. Once they were entered, teaching experience $(\mathrm{p}=.079)$ and degree level $(\mathrm{p}=.092)$ ceased to be significant, as pre-service training $(\mathrm{p}=.077)$. Only in-service training for counselling parents can significantly $(\mathrm{p}=. \mathrm{oo})$ predict preschool teachers' level of ability.

\section{Discussion}

This research indicates that preschool teachers in Croatia consider counselling parents to be an essential aspect of their professional work, and this is connected with their motivation for counselling. Those who considered counselling parents to be a more important aspect of their profession also had a higher level of motivation for counselling parents. 'Competence' is a crucial and broad term in the teaching profession, usually described by knowledge, skills, and abilities. Teachers' experience, knowledge, education in the field of counselling parents, and personal feeling of competence are fundamental concepts, which in the Croatian language is described with the word 'sposobnost', which means 'ability to do'. The closest terms in the English language are 'competence' and 'ability', and the term 'ability' is used in the context of this study as representing the teachers' sense of ability. Self-assessment is a subjective phenomenon and not an easy task for a person to report how much he/she knows and can successfully carry out his/her work (Ricijaš, Huić, \& Branica, 2006). Furthermore, self-assessment is the only effective way to 'start a change in the behavior, because analysis comes from the internal and not some external source' (Ljubetić, 2007, p. 87).

The results have illuminated the teachers' role as professionals who support children and parents with their moderate ability to do so. In line with these findings, counselling parents should be considered to be a very unclear concept in the Croatian preschool context. Apparently, no relevant general specification exists. However, counselling is recognised as a part of cooperation with parents, and its interpretation varies among preschools in Croatia. Cooperation with parents is elaborated in their annual curriculums and covered with approximately $1.5-2 \%$ of work hours (Annual curriculum of preschool, 2013/14a, Annual curriculum of preschool, 2013/14b) through various forms, including group parent meetings, individual consultations, workshops, celebrations, etc. 
Obviously, preschool teachers in Croatia spend a small amount of time in counselling parents as a part of cooperation with them, mostly through individual consultations.

Unprofessional and incompetent counselling may lead to questionable ethical situations that benefit no one. The effect of counselling becomes questionable when the one who provides counselling knows a lot about the problem, but little about education, strategies, and approaches (Brown, 1997; according to Stričević, 2011). Research conducted by Mlinarević and Thomas (2010) and Skočić Mihić and Srića (2016) has shown that parents prefer to first confide in the preschool teacher and only then in experts (psychologist, pedagogic expert, and others). Generally, parents are interested in collaboration with preschool teachers (Petrović-Sočo, 1995).

In contrast, preschool teachers consider themselves to be the parents' supporters (Hirsto, 2010). It is necessary to understand that both stakeholders recognise the benefits, necessity, and possibility of counselling parents. Therefore, the competences of preschool teachers should be strengthened. The present research suggests that it is necessary to develop a concept of counselling in the field of preschool teachers' work with parents. Clearly, the preschool teachers' main focus is the task of educating; they are not counsellors, but 'use counselling skills as part of their jobs some of the time if they are to be maximally effective' (Nelson- Jones, 2007 , p. 4). It takes a small number of the preschool teachers' work schedule, but its effect is significant. In line with this, preschool teachers are professionals who use counselling skills in helping and supporting parents of early and preschoolaged children to ensure appropriate conditions for the fulfilment of the children's potentials and optimal growth and development.

According to the concept of supporting parenting embedded in the legal and theoretical foundations of contemporary childhood, this definition sees the preschool teacher as a partner in strengthening responsible parenting. Giving support to parents by using helping and counselling skills in preschool settings is crucial for the development of the parents' competences. A competent parent sees difficulties as temporary and possible to be overcome; he deliberates and detects 'critical' points of his parenting and uses all available resources to improve his parenting competences (Ljubetić, 2012). It is obvious that counselling can be viewed as one of the organisational forms of parent education. The level of the parents' needs differs from occasional, brief, and single instances of teacher's advice and information to more systematic and long-term assistance (Longo, 2005). The preschool teachers can deal with daily developmental and educational issues in supporting parents. In some specific situations, they must deal with complex issues that require linking multiple experts. Therefore, in 
these situations, a long-term and systematic process of joint action of teachers, experts, and parents is required (Resman, 2000). Thus, counselling parents becomes the teamwork of experts in preschools and preschool teachers as unavoidable stakeholders due to their role in the child's life. However, the point at which preschool teachers and experts unite is unclear, and it has not been formally specified. Generally, preschool teachers perceived inefficient cooperation with experts in counselling parents (Srok \& Skočić Mihić, 2012, 2013), probably due to the unclear professional roles in supporting parents.

Preschool teachers' competence to counsel parents is not related to their perceptions of the importance of counselling parents in preschool teachers' work and their motivation for it. It seems that their competence for counselling parents is strongly associated with the level of knowledge they assess themselves to have about the subject, experience in this area, and their sense of competence for its implementation. It is known that preschool teachers obtain very poor professional knowledge for counselling parents during their tertiary education. It is questionable as to what extent these competences can be acquired during their in-service training in institutions of early and preschool education. Slunjski (2008) discusses the competences approach to professional development, which verifies the knowledge in their daily educational activities and leads to change and development in their own competences, as these results prove. Generally, preschool teachers' competence is associated with their pre- and in-service education. Knowledge and skills for counselling parents acquired throughout education affect the positive image of teachers and supports better self-understanding as well as an understanding of the intergenerational relationships, fostering personal, and family relations, and relations with other significant persons in the life of students (Lin, 2011). Janković (1997) states that knowledge is a crucial factor in the counselling work, although it is not always easily proved by the results of action when resolving the problem.

Preschool teachers' moderate competence to counsel parents correlates with other assessments of their competence, such as competences to work in inclusive settings or competence for collaboration with parents (Erčulj, 2008; Skočić Mihić, 2011). This opens space for the further development of various forms of professional development aimed not only at the advances in knowledge but also at the 'changes in the teacher's beliefs and behavior' (Slunjski, 2008, p. 193).

Ability is obtained throughout in-service training, which raises the question of how and when the novice educators obtained the necessary competences that should be an integral part of their formal undergraduate study. Preschool teachers are entering their careers without adequate training for 
counselling parents, even though it is part of their daily work, as prescribed in one of the key documents.

\section{Conclusion}

The Croatian national policy framework in early and preschool education changes the image of the preschool teachers' profession as well as his/her professional roles on a daily basis. One important area of activity for a new professional is collaboration with the family. Unquestionably, preschool teachers cooperate with parents to further children's social, emotional, and intellectual growth. Therefore, their ability to counsel parents is crucial, not merely because of ethical, professional, and legal obligations for it. It is a truly effective way of helping children, parents, and themselves in everyday challenges. The more the teachers develop their ability to counsel parents, the better the target (child's welfare) is achieved.

Based on the reported moderate ability for it, their competence to counsel parents should be enhanced. It is indisputable that competences to counsel parents should be carefully embedded in pre-service training. This research opens the way for further reflection and creation of the theoretical construct of counselling from the perspective of the preschool teacher as well as for defining the most appropriate forms of cooperation in which the preschool teacher applies counselling, knowing his or her personal competences and with respect to various professionals who are engaged in consulting within their profession.

Lastly, the concept of counselling parents as a professional role of preschool teachers remains quite a vague concept in Croatia, and the findings of this research point to training for counselling as a key role, especially during in-service training. Therefore, is vital to provide a mandatory course to gain competences for counselling parents.

Although the findings of this research have significant implications for supporting preschool teachers' education for counselling parents, there are a few limitations that must be considered. First, the convenience sample for the research includes preschool teachers enrolled at the graduate level of education and their colleagues who were willing to voluntarily take part in the survey, thus limiting the generalisation of the findings. It is possible that the findings may have been different if a larger sample was used across different preschools. In addition, the scale is restricted to the basic concepts of being capable or qualified to counsel parents, as it was measured by just four items.

Another limitation of the present research is that the assessment of the preschool teachers' competence to counsel parents was based on the 
participants' self-reports. Although self-reports have been used for the assessment in different relevant studies, the assessment of parents and experts could lead to a clearer image. However, this research is focused on identifying the areas of counselling parents.

The examinees (i.e., the sample of the preschool teachers in this research) did not participate in any pre-service training on counselling; an elective course has been offered in academic education since 2010. It would be interesting to explore its effect on the competence of preschool teachers in further research.

Further research is needed to: (a) explain the skills and abilities of preschool teachers applied in counselling parents, (b) determine other personal characteristics, (c) form the curriculum during pre-service education to influence their self-assessed ability, and (d) define what kind of skills and abilities they need for counselling parents.

\section{References}

Agbaje, A. A., \& Eyo, U. E. (2011). Counselling psychologists' skills, educational reforms and innovations in Nigeria primary schools. International Journal of Academic Research, 5(3), 307-316. Babić, N., \& Kuzma, Z. (2003). Trideset godina predškolskog odgajatelja u Osijeku [Thirty years of educating preschool teachers in Osijek]. In N. Babić \& S. Irović (Eds.), Dijete i djetinjstvo - teorija $i$ praksa predškolskog odgoja (pp. 35-57). Osijek: Sveučilište J. J. Strossmayera, Visoka učiteljska škola. Bowman, B. T., Donovan, S., \& Burns, M. S. (2000). Eager to learn: Educating our preschoolers. Washington, DC: National Academies Press.

Council of Europe (2006). Recommendation 19 Committee of Ministers to member states of the Council of Europe on policy to support positive parenthood.

Državni pedagoški standard predškolskog odgoja i naobrazbe [The state pedagogical standard of preschool education] (2008). Narodne novine, 63.

Doikou, M., \& Diamandidou, K. (2011). Enhancing teachers' counselling skills: Student teachers' views on a teachers' education programme. European Journal of Teacher Education, 34(1), 61-79. Erčulj, J. (2008). Razvoj metodoloških inštrumentov za ugotavljanje in spremljanje profesionalnega razvoja vzgojiteljev, učiteljev in ravnateljev. Projektno poročilo [The development of methodological instruments for the detection and monitoring of professional development for teachers and school principals. Project report.]. Ljubljana: Pedagoški inštitut. Retrieved from http://www.mizs.gov.si/si/ delovna_podrocja/urad_za_razvoj_izobrazevanja/evalvacija_vzgoje_in_izobrazevanja/evalvacija_ vzgojno_izobrazevalnih_programov/

Godišnji plan i program rada [Annual curriculum of preschool] (2013/14a). Preschool 'Radost'.

Retrieved from http://www.radost-crikvenica.hr/dokumenti/godisnji\%2oplan\%2oi\%2oprogram\%2O rada\%202013-14.pdf

Godišnji plan i program rada [Annual curriculum of preschool] (2013/14b). Preschool 'Pazin'. 
Retrieved from http://www.pazin.hr/picture/upload/File/Godisnji\%2oplan\%2oVrtica.pdf Hackney, H. L., \& Cormier, S. (2012). Savjetovatelj - stručnjak, Procesni vodič kroz pomaganje [The professional counsellor: A process guide to helping]. Jastrebarsko: Naklada Slap.

Hirsto, L. (2010). Strategies in home and school collaboration among early education teachers.

Scandinavian Journal of Educational Research, 54(2), 99-108.

Idowu, A. I. (2004). Guidance and counselling: An overview. In A. I. Idowu (Ed.), Guidance and counselling in education. Ilorin: INDEMAC Publishers.

Ipaye, B. (1995). Guidance and counselling in Nigerian schools. Lagos: Chayoobi Printers and Publishers.

Janković, J. (1997). Savjetovanje nedirektivni pristup [Nondirective counselling]. Zagreb: Alinea. Kaplan, D. M., Tarvydas, V. M., \& Gladding, S. T. (2010). A vision for the future of counselling. American Counselling Association. Retrieved from https://www.counseling.org/docs/defaultsource/20-20/2020-jcd-article-consensus-definition.pdf?sfvrsn=76o17f2c_2

Lin, Y. (2011). Teacher education students' experiences in the course on counselling theory and practice. College Student Journal, 45(2), 242-256.

Longo, I. (2005.). Škola kao mjesto edukacije roditelja za kvalitetno roditeljstvo (Roditelji i učitelji na putu prema kvalitetnoj školi) [The school as a place of education for quality parenting (Parents and teacher on the way to quality school)]. In H. Ivon (Ed.), Prema kvalitetnoj školi: zbornik radova /4. Dani Osnovne škole Splitsko-dalmatinske županije (pp. 130-136). Split: HPKZ Ogranak Split; Zagreb: Hrvatsko filološko društvo - Odjel za metodiku nastave hrvatskog jezika, govornog i pismenog izražavanja, književnosti i medijske kulture.

Ljubetić, M. (2007). Biti kompetentan roditelj [To be a competent parent]. Zagreb: Mali profesor. Ljubetić, M. (2012). Nosi li dobre roditelje roda?! Odgovorno roditeljstvo za kompetentno dijete [Are good parents brought by stork? Responsible parenthood for competent child]. Zagreb: Profil. Mlinarević, V., \& Tomas, S. (2010). Partnerstvo roditelja i odgojitelja - čimbenik razvoja socijalne kompetencije djeteta [Partnership between parents and preschool teachers - factor for developing children's social competences]. Magistra Iadertina, 5(5), 143-158.

Nacionalna klasifikacija zanimanja 2010 - NKZ 10 [National classification of occupations 2010 NCO $\left.10^{\text {th }}\right]$ (2010). Narodne novine, 147. Retrieved from http://www.dzs.hr/Hrv/important/Nomen/ NKZ2010/NKZ_2010.pdf Nacionalna obiteljska politika Republike Hrvatske [The Croatian national family policy] (2003). Zagreb: Državni zavod za zaštitu obitelji, materinstva i mladeži. Retrieved from http://www.uredravnopravnost.hr/site/preuzimanje/dokumenti/nac_strat/nacionalna_obiteljska_politika.pdf Nacionalni okvirni kurikulum za predškolski odgoj i obrazovanje te opće obvezno i srednjoškolsko obrazovanje [National curriculum for pre-school education and general primary and secondary education] (2011). Zagreb: Ministarstvo znanosti obrazovanja i sporta Republike Hrvatske. Retrieved from http://Nacionalni_okvirni_kurikulum_web_listopad_2011.pdf Nelson-Jones, R. (2003). Basic counselling skills: Helper's manual. London, UK: Sage Publications. Nelson-Jones, R. (2007). Praktične vještine u psihološkom savjetovanju [Practical Counselling and 
Helping Skills]. Jastrebarsko: Naklada Slap.

Nelson-Jones, R. (2015). Theory and practice of counselling and psychotherapy. Los Angeles, CA;

London, UK; New Delhi, Singapore \& Washington DC: SAGE Publications.

Oberhuemer, P., Schreyer, I., \& Neuman, M. J. (2010). Professionals in early childhood education and care systems: European profiles and perspectives. Opladen \& Farmington Hills: Verlag Barbara.

Osgood, J. (2010). Reconstructing professionalism in ECEC: The case for the critically reflective emotional professional'. Early Years, 30(2), 119-133.

Pećnik, N., \& Starc, B. (2010). Roditeljstvo u najboljem interesu djeteta i podrška roditeljima najmlađe djece [Parenting in the best interests of the child and the parents support the youngest children]. Zagreb: UNICEF. Retrieved from http://www.unicef.hr/wp-content/uploads/2015/og/Roditeljstvo_u_ najboljem_interesu_djece.pdf

Petrović-Sočo, B. (1995). Ispitivanje stavova roditelja o suradnji s dječjim vrtićima [Research of parents' attitudes concerning cooperation with kindergartens]. Društvena istraživanja, 4(4-5), 613-625.

Resman, M. (2000). Savjetodavni rad u vrtiću i školi [Counselling in kindergartens and schools]. Zagreb: Hrvatski pedagoško-književni zbor.

Ricijaš, N., Huić, A., \& Branica, V. (2006). Zadovoljstvo studijem i samoprocjena kompetentnosti studenata nekih pomagačkih profesija [Satisfaction with education and self-evaluation of students' competency in helping professions]. Hrvatska revija za rehabilitacijska istraživanja, 42(2), 51-68. Rushton, S., \& Larkin, E. (2001). Shaping the environment: Connecting developmentally appropriate practices to brain research. Early Childhood Education Journal, 29(1), 25-33.

Savickas, M. L. (2011). The centennial of counsellor education: Origin and early development of a discipline. Journal of Counselling and Development, 89(3), 500-503.

Shonkoff, J. P., \& Phillips, D.A. (Eds.) (2000). From neurons to neighbourhoods: The science of early child development. A report of the National Research Council. Washington, DC: National Academies Press.

Skočić Mihić, S. (2011). Spremnost odgajatelja i faktori podrške za uspješno uključivanje djece s teškoćama u rani i predškolski odgoj i obrazovanje [Readiness of teachers and support factors for successful inclusion in early and pre-school education. Doctoral Dissertation]. Zagreb: Faculty of Education and Rehabilitation Sciences University of Zagreb.

Skočić Mihić, S., Blanuša Trošelj, D., \& Katić, V. (2015). Odgojitelji predškolske djece i savjetodavni rad s roditeljima [Preschool teachers and counselling parents]. Napredak, 156(4), 385-400. Skočić Mihić, S., \& Srića, S. (2016). Jesu li zadovoljniji roditelji koji češće surađuju s odgajateljima? [Are parents who often cooperate with educators more satisfied?]. In M. Orel (Ed.), Sodobni pristopi poučevanja prihajajočih generacij (pp. 315 - 327). Ljubljana: Eduvision.

Slunjski, E. (2008). Dječji vrtić: zajednica koja uči-mjesto dijaloga, suradnje i zajedničkog učenja [Kindergarten- learning community, a place of dialogue, cooperation and mutual learning]. Zagreb: Spektar Media.

Srok, N., \& Skočić Mihić, S. (2012). Odgajatelji i stručni suradnici u savjetodavnoj ulozi [Preschool 
teachers and associate experts in counselling role]. Dijete Vrtić Obitelj, 18(70), 19-21.

Stričević, I. (2011). Jačanje roditeljskih kompetencija kroz programe obrazovanja roditelja

[Strengthening parenting competences through parent education programmes]. In D. Maleš (Ed.),

Nove paradigme ranog odgoja (pp. 125-151). Zagreb: Filozofski fakultet Sveučilišta u Zagrebu.

Studijski programi [Curriculum of study programmes] (2013). Retrieved from http://www.ufri.uniri.

hr/en/study-programmes.html

Tuna, A., Tankersley, D., Brajković, S., Cincilei, C., Handžar, S., Ibolya, E.,... \& Vonta, T. (2011).

Kompetencije učitelja 21. stoljeća [Competent teacher of the 21st century]. Zagreb: Pučko otvoreno učilište Korak po korak.

Tankersley, D., Brajković, S., Handžar, S., Rimkiene, R., Sabaliauskiene R., Trikić, Z., \& Vonta, T.

(2012). Teorija u praksi: priručnik za profesionalni razvoj odgajatelja [Theory in Practice: A handbook for preschool teacher's professional development]. Zagreb: Pučko otvoreno učilište Korak po korak. The Council of the European Union (2006). Efficiency and equity in European education and training systems. Brussels: The Council of the European Union. Retrieved from https://hal.archives-ouvertes. fr/hal-o0423840/documenthttp://ec.europa.eu/education/policies/2010/doc/comm481_en.pdf The Council of the European Union (2009). Council Conclusions on a strategic framework for European cooperation in education and training ('ET 2020'). Brussels: The Council of the European Union. Retrieved from http://www.consilium.europa.eu/uedocs/cms_data/docs/pressdata/en/ educ/107622.pdf

The Council of the European Union (2011). Council conclusions on early childhood education and care: providing all our children with the best start for the world of tomorrow. Brussels: The Council of the European Union. Retrieved from http://eur-lex.europa.eu/LexUriServ/LexUriServ.do?uri=OJ:C:2011 :175:0008:0010:EN:PDF

UN convention on the rights of the child (2002). Retrieved from http://www.togetherscotland.org.uk/ about-childrens-rights/un-convention-on-the-rights-of-the-child/ Vujičić, L., Čepić, R., \& Lazzarich, M. (Eds.) (2010). Znanstveni doprinos 1998 - 2010 [The scientific contribution 1998-2010]. Rijeka: Učiteljski fakultet Sveučilišta u Rijeci.

Zakon o predškolskom odgoju i obrazovanju [Law of Preschool Education] (1997). Narodne novine, 10. Zambo, D. (2008). Childcare workers' knowledge about the brain and developmentally appropriate practice. Early Childhood Educational Journal, 35(6), 571-577. 


\section{Biographical note}

SANJA Sкос̌ı́́ Mıнıć, $\mathrm{PhD}$, is an assistant professor at the Faculty of Teacher Education, University of Rijeka, Croatia. Her teaching and scientific interest include inclusive and gifted education, teacher competencies for inclusive teaching, counseling, bibliotherapy and classroom management.

Danijela Blanuša Trošelj is an assistant at the Faculty of Teacher Education and doctoral student at Faculty of Education in Ljubljana. Her scientific interest includes professional development and professional ethics in education, gifted children, media and children, and a neurocognitive perspective in educational sciences.

VESNA KATIĆ is a Higher Lecturer, and currently teaches students at the Faculty of Teacher Education, University of Rijeka, Croatia. Her contemporary research interests include early and pre-school education (curriculum, collaboration with parents, observation, monitoring and assessment of child development, documentation of training - educational process, etc.). She is also a trainer of the Open University Step by step in Croatia on the application of quality child centered methodology and application of the ISSA Pedagogical Standards. 